\title{
Clinicopathological Factors Determining the Pathological Response to Neoadjuvant Therapy in HER2 Positive Breast Cancer
}

\author{
HER2 Pozitif Meme Kanserinde Neoadjuvan Tedaviye Patolojik Yanıtı Belirleyen \\ Klinikopatolojik Faktörler
}

\author{
(D) Abdullah Evren YETişiR ${ }^{1}$, (D) Semra PAYDAŞ² \\ ${ }^{1}$ Adana City Training and Research Hospital, Clinic of Medical Oncology, Adana, Turkey \\ ${ }^{2}$ Çukurova University Faculty of Medicine, Department of Oncology, Adana, Turkey
}

\begin{abstract}
Aim: In our study, we aimed to determine the clinicopathological factors affecting the pathological response after neoadjuvant chemotherapy in HER2 positive breast cancer.

Materials and Methods: A total of 54 HER2 expression positive cases were included in this study. Neoadjuvant chemotherapy regimen containing trastuzumab was applied to all patients. Patients' age, gender, disease stage, tumor size and lymph node status, estrogen and progesterone receptor status, Ki-67 proliferation index, tumor grade, menopausal status and pathological complete response status after neoadjuvant therapy, neoadjuvant treatment regimen and the relationship between the tumor and histological subtype were examined.

Results: Grade III tumor, hormone receptor negativity, high Ki-67 score, and the presence of T3 or T4 tumor were found to be better associated with pathological complete response ( $p=0.036, p=0.033, p=0.021, p=0.048$, respectively). High tumor grade, hormone receptor negativity and high Ki-67 score were found as independent risk factors determining pathological complete response ( $p=0.043, p=0.047, p=0.035$, respectively).

Conclusion: In this series of 54 cases with HER2 positive breast cancer, the parameters determining pathological complete response after neoadjuvant treatment are high $\mathrm{Ki}-67$ proliferation index, grade III tumor and hormone receptor negativity.
\end{abstract}

Keywords: Breast cancer, HER2, neoadjuvant, pathological complete response

ÖZ

Amaç: Çalışmamızda HER2 pozitif meme kanserinde neoadjuvan kemoterapi sonrası patolojik yanıtı etkileyen klinikopatolojik faktörleri saptamayı amaçladık.

Gereç ve Yöntem: Bu çalışmaya HER2 ekspresyonu pozitif toplam 54 olgu dahil edildi. Hastaların tamamına trastuzumab içeren neoadjuvan kemoterapi rejimi uygulandı. Hastaların yaşı, cinsiyeti, hastalığın evresi, tümör boyutu ve lenf nodu durumu, östrojen ve progesteron reseptör durumu, Ki-67 proliferasyon indeksi, tümörün grade'i, menopoz durumu ve neoadjuvan tedavi sonrası patolojik tam yanıt durumu, neoadjuvan tedavi rejimi ve tümörün histolojik alt tipi ile arasındaki ilişki incelendi.

Bulgular: Grade III tümör, hormon reseptör negatifliği, Ki-67 skor yüksekliği, T3 veya T4 tümör varlığı daha iyi patolojik tam yanıt ile ilişkili bulundu (sırasıyla $p=0,036, p=0,033, p=0,021, p=0,048$ ). Yüksek tümör grade'i, hormon reseptör negatifliği ve yüksek Ki-67 skoru patolojik tam yanıtı belirleyen bağımsız risk faktörleri olarak saptandı (sırasıyla $p=0,043, p=0,047, p=0,035$ ).

Sonuç: HER2 pozitif meme kanserli 54 olguluk bu seride neoadjuvan tedavi sonrası patolojik tam yanıtı belirleyen parametreler yüksek Ki-67 proliferasyon indeksi, grade III tümör varlığı ve hormon reseptör negatifliğidir.

Anahtar Kelimeler: Meme kanseri, HER2, neoadjuvan, patolojik tam yanıt

Address for Correspondence: Abdullah Evren YETişiR MD, Adana City Training and Research Hospital, Clinic of Medical Oncology, Adana, Turkey Phone: +90 5556828625 E-mail: evrenyetisir@hotmail.com ORCID ID: orcid.org/0000-0001-7214-8184

Received: 03.02.2021 Accepted: 02.04.2021 


\section{INTRODUCTION}

Breast cancer is the most common cancer seen in women. According to Globocan 2020, 23.9\% of cancers seen in women in our country are breast cancer. Breast cancer is the second most common cause of cancer mortality in our country and in the USA ${ }^{1,2}$. Neoadjuvant treatment of breast cancer refers to the systemic treatment of the tumor before surgery. In this way, by shrinking the tumor, breast-conserving surgery can be performed instead of mastectomy, and better cosmetic results can be obtained, and lymphedema that may develop after surgery can be prevented ${ }^{3,4}$. Another important advantage of neoadjuvant therapy is that therapeutic efficacy can be directly observed ${ }^{5}$. It also provides the opportunity for personalized treatment strategies and drug development ${ }^{6}$. Human epidermal growth factor receptor 2 (HER2) is from the family of epidermal growth factor receptors that play a critical role in the activation of subcellular signal transduction pathways which control epithelial cell growth and differentiation ${ }^{7,8}$. Amplification or overexpression of the HER2 oncogene is present in approximately 15\% of invasive breast cancers ${ }^{9}$. Since the presence of HER2 expression is a predictive factor in breast cancer, HER2 expression status should be investigated at the time of diagnosis in breast cancer ${ }^{10}$. In this way, agents targeting HER2 receptors can be used in adjuvant or neoadjuvant therapy ${ }^{11-13}$. To determine the response after neoadjuvant therapy, pathological evaluation of the primary tumor and axillary lymph node is performed, except for negative sentinel lymph node before treatment. The absence of breast and axillary tumors in surgical material indicates pathological complete response (pCR) and is associated with better survival ${ }^{14,15}$. Even if HER2-targeting agents are not used in neoadjuvant therapy in HER2 positive breast cancers, they have better pathological response rates than HER2negative patients ${ }^{16,17}$. Obtaining $\mathrm{pCR}$ after the completion of neoadjuvant therapy and surgical resection is associated with improved disease-free survival. This correlation is dependent on the molecular subtype and is evident in patients with triple negative and HER2 positive breast cancer ${ }^{5}$.

In our study, we aimed to determine the factors affecting the pathological response after neoadjuvant chemotherapy in HER2 positive breast cancer.

\section{MATERIALS AND METHODS}

From a total of 114 stage II and stage III breast cancer women with axillary lymph node involvement, who received neoadjuvant chemotherapy, 54 patients with HER2 expression positive were included. CerbB2 status was determined by immunohistochemical method from the biopsy material of the patients before neoadjuvant chemotherapy. Patients with cerbB2 negative status and 1+ were considered HER2 negative. HER2 expression was evaluated by fluorescent in situ hybridization method (FISH) from the tissues of patients with cerbB2 status of $2++$, and those who were positive were considered HER2 positive. Patients with cerbB2 status of $3+++$ were considered HER2 positive. Neoadjuvant chemotherapy regimen containing trastuzumab was given to all patients who were considered HER2 positive. Those with estrogen or progesterone receptor levels of $\geq 1 \%$ were considered hormone receptor positive, and those with both $<1 \%$ were considered hormone receptor negative. Stage, tumor size and lymph node evaluation (TN) according to the American Joint Committee on Cancer (AJCC) TNM Staging Classification for breast cancer $8^{\text {th }}$ edition staging system including age, gender, tumor size, lymph node positivity and metastasis status of the patients and estrogen progesterone receptor status, Ki-67 proliferation index, tumor grade, menopausal status and pCR status after neoadjuvant treatment, neoadjuvant treatment regimen that was given, and histological subtype of the tumor were evaluated (Table 1).

\section{Statistical Analysis}

After testing the conformity of the data to the normal distribution, those showing normal distribution of continuous variables were analyzed with the t-test, and those that did not show normal distribution were analyzed with the Mann-Whitney $U$ test. The $\chi^{2}$ test was used in the analysis of categorical variables. All numerical data were expressed as mean values or ratios. For data that did not show normal distribution, comparisons between pre-post measurements were made using the Wilcoxon test.

Cox regression analysis was used to analyze univariate and multivariate data. Receiver operating characteristic (ROC) curve analysis was used to determine the Ki-67 cut-off value. Results were expressed as mean \pm standard deviation, median (lower limit and upper limit), number and percentage, and the value of $p<0.05$ was considered statistically significant. Statistical analysis of the data was performed using Statistical Package for the Social Sciences 21.0 software.

This article was approved by Çukurova University Faculty of Medicine Non-Invasive Clinical Research Ethics Committee with the decision number of 54 dated 10.06.2016.

\section{RESULTS}

\section{Patient Characteristics}

All of the patients participating in the study were women. A total of 114 patients who received neoadjuvant chemotherapy were evaluated. Twenty-eight (24.6\%) patients were cerbB2 negative, $4(3.5 \%)$ patients were cerbB2 $1+, 35(30.7 \%)$ patients were cerbB2 $2++$ and $47(41.2 \%)$ patients were cerbB2 $3+++$. 
Table 1. Clinicopathological features of the patients ( $n: 54)$ Number of patients $n(\%)$

Age

$\leq 50$ years

25 (46.3)

$>50$ years

$29(53.7)$

Complete pathological response

Yes

No

$30(55.6)$

Menopausal status

Premenopausal

$24(44.4)$

Postmenopausal

25 (46.3)

ER status

Positive

$29(53.7)$

Negative

38 (70.4)

PR status

16 (29.6)

Positive

23 (42.6)

Negative

31 (57.4)

Hormone receptor negative

Yes

No

16 (29.6)

38 (70.4)

CerbB2 status

$2++$

7 (13)

$3+++$

47 (87)

Ki-67 status (\%)

0-10

11-30

7 (13)

31-50

17 (31.5)

10 (18.5)

$>50$

20 (37)

Tumor grade

Grade I

Grade II

1 (1.8)

Grade III

25 (46.3)

28 (51.9)

\section{T status}

T1

T2

T3

T4

\section{$\mathrm{N}$ status}

N1

N2

N3

Stage

Stage II

Stage III

Histological subtype

IDC

ILC

1 (1.9)

21 (38.8)

7 (13)

25 (46.3)

9 (16.6)

34 (63)

11 (20.4)

7 (13)

47 (87)

40 (74.1)

14 (25.9)

Chemotherapy protocol

$\mathrm{AC} / \mathrm{P}+\mathrm{T}$

23 (42.6)

$\mathrm{TCH}$

25 (46.3)

6 (11.1)

ER: Estrogen receptor, PR: Progesterone receptor, IDC: Invasive ductal carcinoma, ILC: Invasive lobular carcinoma, AC/P+T: Doxorubicin and cyclophosphamide/ paclitaxel+trastuzumab, TCH: Docetaxel, carboplatin and trastuzumab
HER2 expression was detected by FISH method in 7 (6\%) of 35 patients with CerbB2 2++. A total of 54 (47.3\%) HER2 positive patients were evaluated. The median age of the patients included in the study was 52 years (age range: $34-76$ years). The median Ki-67 score was 54\% (range 5-90\%), 20 (37\%) patients had a Ki-67 score $>50 \%$, and $16(29.6 \%)$ patients were hormone receptor negative. Approximately half of the patients had grade III tumors $(n=28,51.9 \%)$ and $29(53.7 \%)$ patients were in the postmenopausal period. While docetaxel, carboplatin, trastuzumab (TCH) chemotherapy protocol was applied to 25 (46.3\%) patients, dose-intensive Doxorubicin and cyclophosphamide/paclitaxel+trastuzumab chemotherapy protocol was applied to $23(42.6 \%)$ patients. Reimbursement for pertuzumab was not available in our country at the time when the patient data were collected. Patients were offered this treatment option, but no patient accepted. Fourty-seven (87\%) of the patients had stage III disease and approximately half had T4 tumor $(n=25,46.3 \%)$ while two-thirds had N2 $(n=34,63 \%)$ disease. When the histological subtypes of the tumors were examined, invasive ductal carcinoma was found in $40(74.1 \%)$ patients.

\begin{tabular}{|c|c|c|c|}
\hline Variable & $95 \% \mathrm{Cl}$ & HR & $p$ value \\
\hline $\begin{array}{l}\text { Age } \\
\leq 50 \text { years }->50 \text { years }\end{array}$ & $0,812-1,891$ & 1,358 & 0.215 \\
\hline $\begin{array}{l}\text { Menopausal status } \\
\text { Premenopausal- } \\
\text { Postmenopausal }\end{array}$ & & & 0.348 \\
\hline $\begin{array}{l}\text { ER status } \\
\text { Positive-Negative }\end{array}$ & $0,785-1,982$ & 1,485 & 0.129 \\
\hline $\begin{array}{l}\text { PR status } \\
\text { Positive-Negative }\end{array}$ & $0,914-1,715$ & 1,286 & 0.132 \\
\hline $\begin{array}{l}\text { Hormone receptor negative } \\
\text { Yes-No }\end{array}$ & $0,658-2,152$ & 1,872 & 0.033 \\
\hline $\begin{array}{l}\text { cerbB2 status } \\
2++-3+++\end{array}$ & $0,751-2,048$ & 1,463 & 0.654 \\
\hline $\begin{array}{l}\text { Tumor grade } \\
\text { Grade II - Grade III }\end{array}$ & $1,219-2,652$ & 2,159 & 0.036 \\
\hline $\begin{array}{l}\text { T status } \\
\mathrm{T} 1 \text { and } \mathrm{T} 2-\mathrm{T} 3 \text { and } \mathrm{T} 4\end{array}$ & $0,955-1,441$ & 1,186 & 0.048 \\
\hline $\begin{array}{l}\text { N status } \\
<\mathrm{N} 3-\mathrm{N} 3\end{array}$ & $0,853-2,125$ & 1,543 & 0.086 \\
\hline $\begin{array}{l}\text { Stage } \\
\text { Stage II - stage III }\end{array}$ & $0,715-2,037$ & 1,422 & 0.732 \\
\hline $\begin{array}{l}\text { Histological subtype } \\
\text { IDC - ILC }\end{array}$ & $0,512-2,214$ & 1,725 & 1.142 \\
\hline $\begin{array}{l}\text { Chemotherapy protocol } \\
\mathrm{AC} / \mathrm{P}+\mathrm{T}-\mathrm{TCH}\end{array}$ & $0,689-2,411$ & 1,642 & 0.865 \\
\hline \multicolumn{4}{|c|}{$\begin{array}{l}\text { HR: Hazard ratio, ER: Estrogen receptor, PR: Progesterone receptor, IDC: Invasive } \\
\text { ductal carcinoma, ILC: Invasive lobular carcinoma, AC/P+T: Doxorubicin and } \\
\text { cyclophosphamide/paclitaxel+trastuzumab, TCH: Docetaxel, carboplatinum and } \\
\text { trastuzumab }\end{array}$} \\
\hline
\end{tabular}




\section{Relationship Between Pathological Response and Clinicopathological Data}

pCR was obtained in $30(55.6 \%)$ of 54 patients. Clinicopathological data of the patients are shown in Table 1.

When the relationship between $\mathrm{pCR}$ and clinicopathological data was examined, no correlation was found among patients' age, menopausal status, estrogen or progesterone receptor positivity, cerbB2 positivity, neoadjuvant chemotherapy protocols, $\mathrm{N}$ status and disease stage according to the TNM staging system, and histological subtype of the tumor $(p>0.05)$. Higher rate of $p C R$ was detected in the presence of grade III tumor, hormone receptor negativity, high Ki-67 score, and T3 or T4 tumors ( $p=0.036, p=0.033, p=0.021$ and $p=0.048$, respectively) (Table 2 ). In the multivariate analysis performed to determine whether the variables associated with $\mathrm{pCR}$ were an independent risk factor, the presence of high tumor grade, negative hormone receptor and high Ki-67 score were found to be independent risk factors determining $\mathrm{pCR}$ after neoadjuvant therapy in HER2 positive breast cancer patients ( $p=0.043, p=0.047, p=0.035$, respectively) (Table 3 ).

The most sensitive and specific values for study variables were determined using ROC curve analysis: The cut-off value for Ki67 was $27.5 \%$ (Figure 1).

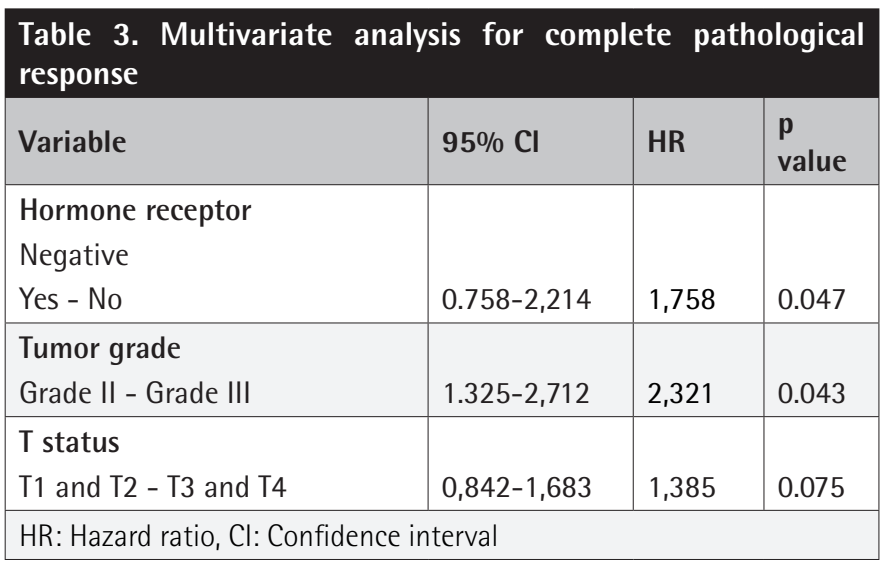

\section{DISCUSSION}

In our study, we aimed to investigate the factors affecting $\mathrm{pCR}$ in patients with HER2-positive breast cancer, and we found that hormone receptor negative, high $\mathrm{Ki}-67$ score and the presence of high-grade tumor were independent risk factors affecting $\mathrm{pCR}$.

Cortazar et al. ${ }^{16}$ evaluated 12 international studies on neoadjuvant therapy. They found that HER2 positive patient group had higher $\mathrm{pCR}$ than those with hormone receptor negative. In the study of Untch et al. ${ }^{18}$, although a higher $\mathrm{pCR}$ was shown in hormone receptor negative patients, the hormone receptor status was not statistically significant other than survival. In our study, we found that the hormone receptor

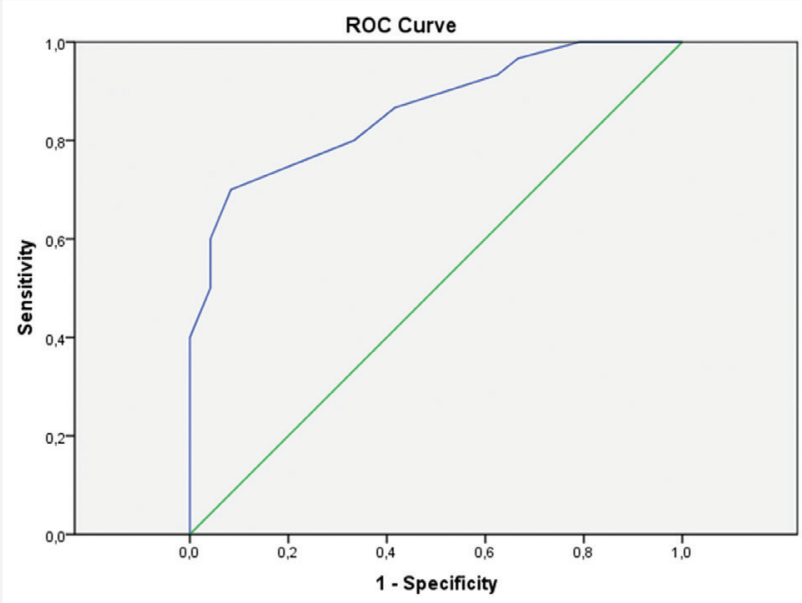

Figure 1. ROC analysis and AUC for Ki-67 sensitivity and specificity. The calculated area under the curve (AUC) is 0.861

ROC: Receiver operating characteristic

negative group had a higher rate of $\mathrm{pCR}$, and we revealed that hormone receptor negativeness was an independent risk factor determining $\mathrm{pCR}$ alone in patients with HER2-positive breast cancer (HR: 1,758, 95\% Cl: 0.758-2,214).

In another study by Cortazar and Geyer ${ }^{19}$, it was stated that $\mathrm{pCR}$ was lower with neoadjuvant therapy in patients with low-grade tumors. However, it was emphasized in the study that this group was a hormone receptor positive group. In the study of Jarzab et al. ${ }^{20}$, tumor grade, Ki-67 and estrogen, and progesterone receptor negativity were determined as pCR-related tumor parameters. The highest chance of $\mathrm{pCR}$ was observed in patients with high grade tumor and $\mathrm{Ki}-67 \geq 20 \%$. Tumor grade and estrogen receptor status were predictive for $\mathrm{pCR}$ independent of other analyzed parameters. In the study of Spring et al. ${ }^{21}$, it was reported that higher $\mathrm{pCR}$ rates were observed in patients with grade 3 tumors. In the study of Karatas et al. ${ }^{22}$ in our country, no significant relationship was found between $p C R$ and T status, but a significant relationship was found with grade. In our study, we found that a higher rate of pCR was obtained with neoadjuvant therapy in high-grade breast cancer patients independent of hormone receptor status as in the hormone receptor negative group, and tumor grade was an independent risk factor, similar to hormone receptor negativity [hazard ratio (HR): 2,321, 95\% confidence interval (CI): 1,325-2,712].

In the study of Silva et al. ${ }^{23}$, it was shown that patients with high Ki-67 proliferation index had a better response to neoadjuvant chemotherapy and had a higher rate of clinical complete response. In this study, the cut-off value for Ki-67 was taken as $14 \%(p=0.005)$. In the study, different cut-off values in Ki-67 expression were also examined and it was found that with increasing cut-off value for the predictive test, its 
sensitivity decreased and its specificity increased. In our study, we showed that a Ki-67 proliferation index higher than 27.5\% would provide a higher rate of $\mathrm{pCR}$ after neoadjuvant therapy, and we found it to be an independent risk factor.

In the study of Untch et al. ${ }^{24}$, in which they evaluated $\mathrm{pCR}$ with neoadjuvant therapy in HER2 positive breast cancer patients, no difference was found between patients with tumors larger than $4 \mathrm{~cm}$ and those with tumors smaller than $4 \mathrm{~cm}$. In our study, although there was a statistically significant difference in univariate analysis between patients with $\mathrm{T} 1$ or $\mathrm{T} 2(\leq 5 \mathrm{~cm})$ tumors and patients with $\mathrm{T} 3$ or $\mathrm{T} 4(>5 \mathrm{~cm})$ tumors for $\mathrm{pCR}$, it was not found to be an independent risk factor in multivariate analysis.

\section{Study Limitations}

The limitations of our study are the lack of pertuzumab use and the small number of patients. Further studies with more patients treated with new targeted agents are needed.

\section{CONCLUSION}

Factors determining $\mathrm{pCR}$ after neoadjuvant therapy in HER2 positive breast cancer patients are Ki-67 proliferation index, tumor grade and hormone receptor negativity. Longer diseasefree survival can be achieved by obtaining $\mathrm{PCR}$ with ideal neoadjuvant therapy in selected patient groups.

\section{Ethics}

Ethics Committee Approval: This article was approved by Çukurova University Faculty of Medicine Non-Invasive Clinical Research Ethics Committee with the decision number of 54 dated 10.06.2016.

Informed Consent: Retrospective study.

Peer-review: Externally peer-reviewed.

\section{Authorship Contributions}

Surgical and Medical Practices: A.E.Y., Concept: A.E.Y., S.P., Design: A.E.Y., S.P., Data Collection or Processing: A.E.Y., S.P., Analysis or Interpretation: A.E.Y., S.P., Literature Search: A.E.Y., S.P., Writing: A.E.Y., S.P.

Conflict of Interest: No conflict of interest was declared by the authors.

Financial Disclosure: The authors declared that this study received no financial support.

\section{References}

1. Sung H, Ferlay J, Siegel RL, Laversanne M, Soerjomataram I, Jemal A, et al. Global Cancer Statistics 2020: GLOBOCAN Estimates of Incidence and Mortality Worldwide for 36 Cancers in 185 Countries. CA Cancer J Clin. 2021;71:209-49.

2. Siegel RL, Miller KD, Jemal A. Cancer statistics, 2020. CA Cancer J Clin. 2020;70:7-30.

3. Kaufmann M, Hortobagyi GN, Goldhirsch A, Scholl S, Makris A, Valagussa $P$, et al. Recommendations from an international expert panel on the use of neoadjuvant (primary) systemic treatment of operable breast cancer: an update. J Clin Oncol.
2006;24:1940-9.

4. Mamtani A, Barrio AV, King TA, Van Zee KJ, Plitas G, Pilewskie M, et al. How Often Does Neoadjuvant Chemotherapy Avoid Axillary Dissection in Patients With Histologically Confirmed Nodal Metastases? Results of a Prospective Study. Ann Surg Oncol. 2016;23:3467-74.

5. Fowler AM, Mankoff DA, Joe BN. Imaging Neoadjuvant Therapy Response in Breast Cancer. Radiology. 2017;285:358-75.

6. Untch $\mathrm{M}$, Konecny GE, Paepke $\mathrm{S}$, von Minckwitz G. Current and future role of neoadjuvant therapy for breast cancer. Breast. 2014;23:526-37.

7. Klapper LN, Glathe S, Vaisman N, Hynes NE, Andrews GC, Sela M, et al. The ErbB-2/ HER2 oncoprotein of human carcinomas may function solely as a shared coreceptor for multiple stroma-derived growth factors. Proc Natl Acad Sci U SA. 1999;96:49955000.

8. Karunagaran D, Tzahar E, Beerli RR, Chen X, Graus-Porta D, Ratzkin BJ, et al. ErbB-2 is a common auxiliary subunit of NDF and EGF receptors: implications for breast cancer. EMBO J. 1996;15:254-64.

9. King CR, Kraus MH, Aaronson SA. Amplification of a novel v-erbB-related gene in a human mammary carcinoma. Science. 1985;229:974-6.

10. Nicolini A, Ferrari P, Duffy MJ. Prognostic and predictive biomarkers in breast cancer: Past, present and future. Semin Cancer Biol. 2018;52:56-73.

11. Walker RA, Bartlett JM, Dowsett M, Ellis IO, Hanby AM, Jasani B, et al. HER2 testing in the UK: further update to recommendations. J Clin Pathol. 2008;61:818-24.

12. Wolff AC, Hammond ME, Hicks DG, Dowsett M, McShane LM, Allison KH, et al. Recommendations for human epidermal growth factor receptor 2 testing in breast cancer: American Society of Clinical Oncology/College of American Pathologists clinical practice guideline update. J Clin Oncol. 2013;31:3997-4013.

13. Gralow JR, Burstein HJ, Wood W, Hortobagyi GN, Gianni L, von Minckwitz G, et al Preoperative therapy in invasive breast cancer: pathologic assessment and systemic therapy issues in operable disease. J Clin Oncol. 2008;26:814-9.

14. Fayanju OM, Ren $Y$, Thomas SM, Greenup RA, Plichta JK, Rosenberger LH, et al. The Clinical Significance of Breast-only and Node-only Pathologic Complete Response (pCR) After Neoadjuvant Chemotherapy (NACT): A Review of 20,000 Breast Cancer Patients in the National Cancer Data Base (NCDB). Ann Surg. 2018;268:591-601.

15. Spring LM, Fell G, Arfe A, Sharma C, Greenup R, Reynolds KL, et al. Pathologic Complete Response after Neoadjuvant Chemotherapy and Impact on Breast Cancer Recurrence and Survival: A Comprehensive Meta-analysis. Clin Cancer Res. 2020;26:2838-48.

16. Cortazar P, Zhang L, Untch M, Mehta K, Costantino JP, Wolmark N, et al. Pathological complete response and long-term clinical benefit in breast cancer: the CTNeoBC pooled analysis. Lancet. 2014;384:164-72.

17. Esserman U, Berry DA, DeMichele A, Carey L, Davis SE, Buxton M, et al. Pathologic complete response predicts recurrence-free survival more effectively by cancer subset: results from the I-SPY 1 TRIAL--CALGB 150007/150012, ACRIN 6657. J Clin Oncol. 2012;30:3242-9.

18. Untch $M$, Fasching $P A$, Konecny $G E$, Hasmüller $S$, Lebeau $A$, Kreienberg $R$, et al. Pathologic complete response after neoadjuvant chemotherapy plus trastuzumab predicts favorable survival in human epidermal growth factor receptor 2-overexpressing breast cancer: results from the TECHNO trial of the AGO and GBG study groups. J Clin Oncol. 2011;29:3351-7.

19. Cortazar P, Geyer CE Jr. Pathological complete response in neoadjuvant treatment of breast cancer. Ann Surg Oncol. 2015;22:1441-6.

20. Jarząb $M$, Stobiecka $E$, Badora-Rybicka A, Chmielik $E$, Kowalska $M, B a l$, et al Association of breast cancer grade with response to neoadjuvant chemotherapy assessed postoperatively. Pol J Pathol. 2019;70:91-9.

21. Spring L, Greenup R, Niemierko A, Schapira L, Haddad S, Jimenez R, et al. Pathologic Complete Response After Neoadjuvant Chemotherapy and Long-Term Outcomes Among Young Women With Breast Cancer. J Natl Compr Canc Netw. 2017;15:121623.

22. Karatas F, Erdem GU, Sahin S, Aytekin A, Yuce D, Sever AR, et al. Obesity is an independent prognostic factor of decreased pathological complete response to neoadjuvant chemotherapy in breast cancer patients. Breast. 2017;32:237-44.

23. Silva LRD, Vargas RF, Shinzato JY, Derchain SFM, Ramalho S, Zeferino LC. Association of Menopausal Status, Expression of Progesterone Receptor and Ki67 to the Clinical Response to Neoadjuvant Chemotherapy in Luminal Breast Cancer. Rev Bras Ginecol Obstet. 2019;41:710-7.

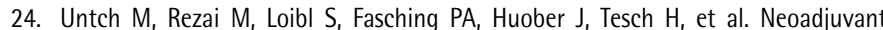
treatment with trastuzumab in HER2-positive breast cancer: results from the GeparQuattro study. J Clin Oncol. 2010;28:2024-31. 